\title{
Afterword: Lives Interrupted, Trends Continued?
}

\section{KENNETH POMERANZ (1)}

The COVID-19 pandemic is nowhere near over. Some things, however, seem relatively clear. So far, the agendas of the world's most powerful actors seem unchanged-or, indeed, accelerated. Partly as a result, disease mortality and economic losses have fallen largely on poorer people, though deaths so far have been concentrated among poorer people in rich countries. Consequently, the pandemic's implications look very different at the local, subnational, and international levels - although at all levels, they thus far reflect accelerations of preexisting trends more than new departures. Many developments reflect remarkable gains in human capacity to cope with disasters - a point highlighted by comparisons to the $1919 \mathrm{flu}$ and other historical events pandemics made by the authors in this forum. Those gains are particularly evident in Asia, though they look more precarious in South Asia and Southeast Asia than in East Asia; this has contributed to a marked shift in rhetoric about global "sickness" and health and seems consistent with prophecies of a coming "Asian century." However, COVID-19 may not be a singular event like 1919 but may portend a wave of environmental emergencies; in that scenario, no world region has exhibited as much resilience as it would need.

Keywords: COVID-19, East Asia, South Asia, migrants, inequality, racism, telecommunications, environmental crisis, global politics, poverty

$\mathrm{T}$ HIS CAN ONLY BE an afterword to this forum. The pandemic itself is far from over; the majority of infections are probably still to come, their distribution unknown. To a significant extent, this is also true of the virus's impact on politics, media, and economics, though some grim results seem sadly predictable: notably, economic burdens are falling disproportionately on people with little to spare, causing a large increase in global poverty. ${ }^{1}$ With so much uncertainty about the present, even reflections on the past, or at least on the past's meanings for the present, are up in the air. Still, some important insights emerge from these excellent essays.

First, nothing has changed so little, thus far, as the agendas of the very powerful. Be it efforts toward increasing discipline and political centralization in Xi Jinping's China, the hostility to Muslims and indifference to the poor of the Bharatiya Janata Party and its

Kenneth Pomeranz (kpomeranzl@uchicago.edu) is University Professor of Modern Chinese History, East Asian Languages and Civilization, and in the College at the University of Chicago.

${ }^{1}$ Daniel Gerszon Mahler, Cristoph Lanker, R. Andres Castaneda Aguilar, and Haoyu Wu, "Projected Poverty Impacts of Covid-19 (Coronavirus)," June 8, 2020, http://pubdocs.worldbank.org/ en/461601591649316722/Projected-poverty-impacts-of-COVID-19.pdf (accessed July 24, 2020). The authors estimate that by the middle of 2021, the effects of COVID-19 will mean 71 million to 100 million more people living in extreme poverty (defined as an income of US $\$ 1.90$ per day, adjusted for purchasing power parity) and 176 million to 230 million more people will be pushed under $\$ 3.20$ per day. 
allies in India or-looking beyond Asia—attacks on science, civil servants, immigrants, and low-wage workers in the United States, the story is "more of the same," not new departures. The pandemic may yet derail some ambitions of the most manifestly irresponsible leaders (notably Donald Trump and Jair Bolsonaro, who combine especially egregious policy failures with especially obvious indifference), but in general, COVID-19 has not disturbed, and has often facilitated, authoritarians' further power grabs. (The crackdown in Hong Kong and accelerated collection of biometric data in China are but two examples.) As David Arnold puts it with respect to India, "an epidemic, still more a pandemic, forces social [and political] divisions more starkly into the open, transforming fissures into fault lines."

Second, looking back even a hundred years demonstrates that the human capacity to cope with pandemic disease has greatly increased-even if we probably feel no more in control than our forebears did. Even without (so far) a vaccine, it appears possible, given sufficient political will and infrastructure, to contain mortality to a degree that was unimaginable in 1919, when perhaps fifty million people died. (This would equal more than 230 million deaths today-roughly four hundred times the COVID toll so far.) Nor-contra some Westerners' dark portrayals of East Asia's comparative success-is this capacity limited to "techno-Orientalist" lands of "hyper-surveillance and denunciation." As Jaeho Kang notes, South Korea has kept its death rate low "without draconian restrictions on speech and movement"; this is even truer of Taiwan and Japan. Japan's story is especially striking: with the world's highest percentage of people aged sixty-five and over, ${ }^{2}$ high population density, heavy reliance on mass transit, and a national government without clear legal authority to order lockdowns, ${ }^{3}$ it might have seemed, ex ante, like one of the most vulnerable rich countries. (Moreover, though Japan is certainly a high-tech society, Japanese have not, as Kate McDonald notes, been particularly enthusiastic about online or cashless purchasing-tech-happy behaviors that have proved very adaptive in this crisis.) Mainland Southeast Asia has had very low death rates so far ${ }^{4}$-and whatever else those varied societies may be, none much resembles the "techno-Orientalist" stereotype. The comparative success of much of Asia in resisting the virus so far is all the more striking in light of the exceptional population densities in many of its cities (and even some rural areas), which makes contagion far more likely. ${ }^{5}$

\footnotetext{
${ }^{2}$ World Bank, "Population Ages 65 and Above," https://data.worldbank.org/indicator/SP.POP.65UP. TO.ZS (accessed July 24, 2020).

${ }^{3}$ Christian Hess, "Lockdown Stories: Spending the Global Pandemic in Tokyo," June 9, 2020, https://warwick.ac.uk/fac/arts/history/ghcc/blog/lockdown_stories_spending (accessed July 24, 2020).

${ }^{4}$ Hannah Beech, "No One Knows What Thailand Is Doing Right, but So Far, It's Working," New York Times, July 16, 2020, https://www.nytimes.com/2020/07/16/world/asia/coronavirusthailand-photos.html (accessed July 24, 2020).

${ }^{5}$ Manabu D. Yamanaka, Kozan Osamu, and Kaoru Sugihara, "Population Density, Personal Distance and Social Distancing in the Anthroposohere" (Research Institute for Humanity and Nature, Kyoto University, 2020), https://www.chikyu.ac.jp/rihn_e/covid-19/topics.html\#topics7 (accessed July 24, 2020). The authors find strong relationships between population density and infection rates within Japan, Indonesia, the United States, and Europe (broadly defined). This contrasts sharply with the pattern between global regions, at least so far.
} 
These relative successes against the virus make more visible the suffering created by draconian containment measures_-vividly portrayed in John Harriss's account of Indiaalong with the places, thus far mostly non-Asian, where containment has failed, or barely been tried. (As I write, however, reported cases in India are spiking, reminding us how tentative our conclusions must be, and that imposing great sacrifices does not ensure success in this any more than in other endeavors. The Philippines and Indonesia-the latter thus far a comparative success story, especially in per capita terms-are also seeing worrisome signs. $\left.{ }^{6}\right)$ It is also worth remembering that our enhanced virus-resisting capacity is organizational and political as well as technological. Having labs that sequence DNA matters, but so does having a World Health Organization and national health agencies, as well as communications networks that allow people to access many kinds of information (and, sadly, disinformation) from varied sources.

Third, the pandemic reminds us yet again that global phenomena are experienced locally—and nationally, since government policy can be crucial. Indeed, the very high percentage of infections and deaths attributable to a few specific environments that concentrate people, whether wholly involuntarily (prisons and US immigrant detention centers), semi-involuntarily (long-term care facilities), semi-voluntarily (high-risk job sites, where low-paid workers often have little alternative to working), or voluntarily (churches, cruise ships, parties, funerals) makes clear that safety often depends less on whether one's general region is linked to Wuhan-eventually, it seems, every place is-than on the efforts made to exclude the virus from, or control it within, very local spaces. Moreover, that means that statements about the distribution of COVID-19 burdens look different at different scales. Thus far (remembering that our data are poor and the situation is fluid), deaths from the virus seem disproportionately concentrated among poorer people in rich Western countries, ${ }^{7}$ who have also done comparatively poorly during the globalization of the last 40 years—at least as measured by percentage changes in income. ${ }^{8}$ That also

6“'India’s Coronavirus Epidemic Overtakes Russia as Indonesia, Philippines See Continued Surge," South China Morning Post, July 6, 2020, https://www.scmp.com/news/asia/southeast-asia/article/ 3091940/coronavirus-cases-surge-philippines-while-indonesia (accessed July 24, 2020).

${ }^{7}$ Jarvis T. Chen and Nancy Krieger, "Revealing the Unequal Burden of COVID-19 by Income, Race/ Ethnicity, Household Crowding: US County vs. ZIP Code Analysis" (working paper, Harvard Center for Population and Development Studies, April 21, 2020), https://cdn1.sph.harvard.edu/wp-content/ uploads/sites/1266/2020/04/HCPDS_Volume-19_No_1_20_covid19_RevealingUnequalBurden_ HCPDSWorkingPaper_04212020-1.pdf (accessed July 24, 2020). For a skeptical view of the national death statistics suggesting that mortality must be much higher than reported in many poor countries, see Philip Schellekens and Diego Sourrille, "COVID-19 Mortality In Rich and Poor Countries: A Tale of Two Pandemics?" (Policy Working Paper 9260, World Bank, revised May 28, 2020), https:/documents.worldbank.org/en/publication/documents-reports/documentdetail/ 559181590712052524/covid-19-mortality-in-rich-and-poor-countries-a-tale-of-two-pandemics (accessed July 24, 2020).

${ }^{8}$ Facundo Alvaredo, Lucas Chancel, Thomas Piketty, Emmanuel Saez, and Gabriel Zucman, "The Elephant Curve of Global Inequality and Growth," American Economics Association Papers and Proceedings 108 (2018):103-8, https://pubs.aeaweb.org/doi/pdfplus/10.1257/pandp.20181073 (accessed July 24, 2020). The middle and lower classes in Japan have shared the economic fate of their Western peers (James Mayger and Hannah Dormido, "The Rich Are Getting Richer in Abe’s Japan,” Bloomberg News, December 13, 2017, https://www.bloomberg.com/graphics/2017japan-inequality/ [accessed July 24, 2020]), but not their experience of COVID-19. Nonelite 
means that the pandemic's implications for international affairs might be quite different from the implications for national and subnational politics - in which they so far mostly seem to be reinforcing existing hierarchies and inequalities. We will return to this difference later.

Fourth, a century's retrospect demonstrates, unsurprisingly, that messaging wars in which states and other actors try to avoid blame for mass contagion, and assign it to disfavored "others," are anything but new. (Indeed, scapegoating for natural disasters goes back as far as our records do.) But they also suggest that those messaging wars are more multisided and more evenly contested than they used to be. There are many possible reasons for this, including changing power relations, more widespread discomfort with racism, and the fact that the most stunning examples so far of dysfunctional responses to COVID-19 come from Western governments, both in rich societies (the United States, the United Kingdom, and Sweden) and not-so-rich ones (Brazil and Mexico). Whatever the reasons, it appears that, despite absurd and immoral attempts to racialize the virus (e.g., Trump's "Kung flu”), cases of anti-Asian harassment and violence, and a wide variety of conspiracy theories appearing on websites worldwide, efforts to equate Asia with sickness are getting far less traction than they used to.

Let me expand briefly on each of these points, drawing upon the forum's articles.

Sadly, the first observation - that the pandemic has generally reinforced the agendas of the powerful-will probably command the quickest assent. While COVID-19 has ruined innumerable individual and local plans, one finds few cases in which major power holders have aborted or substantially altered their agenda, or even made major concessions to gain consent for the sacrifices imposed to fight the pandemic. As Harriss notes, the subsidy programs for the poor in India-especially for millions of very hard-hit migrant workers-have been much stingier than advertised. Nor has the curtailment of internet service in Kashmir been eased during an emergency that makes people far more dependent on computers and cell phones for essential information and social support. ${ }^{9}$ China has intensified its pressure on targets ranging from Hong Kong demonstrators to lawyers, academic dissenters, and spreaders of "rumors," including the Wuhan diarist Fang Fang and her publishers and translators overseas. ${ }^{10}$

It is, of course, impossible to know how many people really support or oppose such repressive actions, but Beijing's crackdowns have many online cheerleaders, and Harriss cites evidence that Modi remains exceptionally popular. We do not yet know whether any of the governments that have handled the virus especially poorly so far-most of them, to varying degrees, electoral democracies (and most of them non-Asian)—will be derailed

\footnotetext{
Russians have done worse; all other Eurasian and North American groups better. I have not found comparable data for Latin America, the Middle East, or Africa.

${ }^{9}$ Ahmer Khan and Billy Perrigo, "What Life Is Like Inside the World's Longest Lockdown," Time, May 5, 2020 https://time.com/5832256/kashmir-lockdown-coronavirus/ (accessed July 24, 2020).

${ }^{10}$ Echo Xie, "Coronavirus Journal Wuhan Diary Continues to Upset Chinese Nationalists," South China Morning Post, May 2, 2020, https:/www.scmp.com/news/china/society/article/3082575/ coronavirus-journal-wuhan-diary-continues-upset-chinese (accessed July 24, 2020); Michael Berry, "I Translated 'Wuhan Diary' to Amplify the Author's Voice of Courage," Washington Post, June 25, 2020, https://www.washingtonpost.com/opinions/2020/06/25/i-translated-wuhandiary-amplify-authors-voice-courage/ (accessed July 24, 2020).
} 
by their failures. (This may be the only area in which the United States is a relative bright spot, as polls show Trump losing badly—and even that remains uncertain.)

Productive projects have suffered more than repressive ones, particularly those requiring travel. McDonald shows us that one big postponed project-the Tokyo Olympics—-was very much designed to buttress the Abe Shinzō government. But, as she also notes, the Olympics is postponed, not canceled, and the government's narrative of a "Recovery Games" - which now has a global referent to go with the national ones of Fukushima and economic stagnation—may become even more resonant. China's stimulus package, announced in late May, focuses mostly on infrastructure projects, without particularly prioritizing places, individuals, or industries that have suffered most from COVID-19 lockdowns. ${ }^{11}$

Second, while our limited control over our own destinies is very much on display now, it is also worth noting how much human capabilities have increased since 1919not to mention earlier pandemics. The biomedical and communications aspects of this are especially striking. Even without a vaccine or generally effective drugs (so far), ventilators have kept many critically ill patients alive, while communications technologies have enabled many millions of people to share information, sustain their occupations and incomes, entertain themselves, and keep in touch while maintaining social distancing. One can debate how much contact tracing must rely on high-tech methods such as those in South Korea highlighted by Kang; but just 30 years ago, most of the world's people had no telephone service inside their homes. ${ }^{12}$

The extent to which technologies and information capable of helping millions actually do so also reflects political change—including the limited but real gains for most Asians from decolonization. Mary Augusta Brazelton rightly reminds us that China was heavily involved throughout the twentieth century in the construction of global public health, rather than being a late joiner to systems built by Westerners. She also rightly emphasizes that late Qing and Republican governments-which had much else to worry about—made those efforts partly to defend their already impaired sovereignty from powers always ready to justify further infringements as self-defense against contagion, ${ }^{13}$ necessitated by the hygienic deficiencies of the "native" regime and population.

\footnotetext{
${ }^{11}$ Amanda Lee, "Coronavirus: China Stimulus Policies Not Enough to Boost Job Growth, Experts Warn,” South China Morning Post, June 9, 2020, https://www.scmp.com/economy/china-economy/ article/3088248/coronavirus-china-stimulus-policies-not-enough-boost-job (accessed July 24, 2020).

${ }^{12}$ Around 2000, many experts still estimated that half the world's population had never made a phone call, and a 1999 paper calculated that 84 percent of cell phones were in wealthy countries with 15 percent of the global population. Today, roughly 85 percent of adults worldwide have a cell phone. See Geoffrey Kirkman, "It's More than Just Being Connected" (paper presented at the Development E-Commerce Workshop, Massachusetts Institute of Technology, August 16-17, 1999), 3-4, https://cyber.harvard.edu/itg/libpubs/beingconnected.pdf (accessed July 24, 2020), For contemporary cell phone ownership statistics, see Laura Silver, "Smartphone Ownership Is Growing Rapidly around the World, but Not Always Equally," Pew Research Center, February 5, 2019, https://www.pewresearch.org/global/2019/02/05/smartphone-ownership-is-growing-rapidlyaround-the-world-but-not-always-equally/ (accessed July 24, 2020).

${ }^{13}$ See, for instance, "Christos Lynteris, "Epidemics as Events and as Crises: Comparing Two Plague Outbreaks in Manchuria (1910-1911 and 1920-1921)," Cambridge Journal of Anthropology 32, no. 1 (2014): 62-76; Sean Hsiang-lin Lei, "Sovereignty and the Microscope: Constituting Notifiable
} 
Looking beyond Brazelton's China-focused essay, it is worth remembering that for roughly half of the twentieth century, people from most of Asia-even if they were as accomplished as Wu Lien-teh (Liande) or Sze Sze-ming (Shi Siming) — could not have participated as these "Chinese"14 figures did in shaping global health, because they were still colonial subjects. Had the North Manchurian plague of 1910-11 broken out instead in, say, Bengal or Sumatra, it is very unlikely that a "native" doctor would have been placed in charge of the response, as Wu was; and China had a seat at the founding conference of the United Nations, from which Sze could push for a World Health Organization, while Vietnam, Burma, and so on did not.

Moreover, as Elizabeth Chatterjee recently showed in this journal, ${ }^{15}$ the provision of electricity to all—or at least the promise thereof, fulfilled to various degrees in various Asian countries-cannot be divorced, historically, from the creation of national regimes that felt at least some pressures to include all their citizens in their modernizing projects. Electrification under early twentieth-century colonial or semicolonial regimes, led by private firms, looked markedly different, focusing on a few industrial users, wealthy urbanites, and institutions such as prisons, hospitals, and government offices. Without today's relatively inclusive power grid, not only the communications technologies noted earlier, but many other things that have made lockdowns more endurablefrom food refrigeration to lighting-would have been far less accessible to enormous numbers of Asians.

This is not to minimize the painfully obvious limits on our control of the virus, the equally obvious pain that has been inflicted by quarantines and other control measures, or the fact that that pain has fallen very disproportionately on the strongly overlapping sets of people who do physical work, who have migrated to work, who lack substantial savings, and who live and work in crowded settings. Nor should we overlook the possibility, noted earlier, that the current concentration of virus deaths in richer countries could change quickly. And for all the gains in connecting poor people worldwide to some kinds of infrastructure and services, the larger picture remains one of huge inequalities in wealth and power, which have not narrowed much in recent decades ${ }^{16}$ and will probably widen further due to lost work, post-COVID-19 government austerity programs, and

Infectious Disease and Containing the Manchurian Plague (1910-1913), in Health and Hygiene in Chinese East Asia: Policies and Publics in the Long Twentieth Century, eds. Angela Leung and Charlotte Furth (Durham, N.C.: Duke University Press, 2010), 73-106. More generally, see Ruth Rogaski, Hygienic Modernity: Meanings of Health and Disease in Treaty Port China (Berkeley: University of California Press, 2004).

${ }^{14}$ One irony here is that $\mathrm{Wu}$ himself was from Penang, and thus a colonial rather than a Chinese subject.

${ }^{15}$ Elizabeth Chatterjee, "The Asian Anthropocene: Electricity and Fossil Developmentalism," Journal of Asian Studies 79, no. 1 (2020): 3-24.

${ }^{16}$ Philip Alston, "The Parlous State of Poverty Eradication" (United Nations Human Rights Council, Report of the Special Rapporteur on Extreme Poverty and Human Rights, July 2, 2020), https://chrgj.org/wp-content/uploads/2020/07/Alston-Poverty-Report-FINAL.pdf (accessed July 24, 2020). Alston provides a critique of optimistic claims about poverty eradication over the last 30 years, especially outside East Asia. Pages 15-16 provide a number of estimates of the separate but related problems of wealth and income inequality. 
limited access for informal sector workers in particular to many relief programs that do exist. (These are often matters of policy, not technological incapacity.) But at the level of a century or two, there have been many positive developments: perhaps most of all in East Asia, where convergence toward "first-world" incomes has gone furthest, the last few months' public health accomplishments seem relatively solid, and the economic damage from lockdowns will probably be less ruinous than in the many countries with weaker safety nets and/or more dependence on overseas remittances.

This essay's third observation-that global phenomena are refracted through the national and the local-is the most abstract, and it can easily dissolve into platitudes about things being "the same but different" across multiple locales. But it is also central to the work many of us do: distinguishing systematic from coincidental resemblances, and random differences from those attributable to structure and/or intent, at various levels of granularity.

It is probably intrinsic to lockdowns and quarantines that they will hit migrants especially hard, unless they are coupled with well-targeted assistance; migrants rarely have the power to compel such accommodations. A late March 2020 survey suggested that China's lockdown had already cost its migrant workers at least US $\$ 100$ billion in lost wages, though it had also been effective in keeping villages virus-free. ${ }^{17}$ China was relatively well-prepared, having rebuilt its public health system since roughly 2000 (and especially since SARS) precisely with an eye toward containing epidemics. ${ }^{18}$ It was also lucky, having been able to start its lockdown when huge numbers of migrants were back in their villages for the annual New Year's break: expecting some time without work, and able to access some social supports, spend time with otherwise seldom-seen family members, and avoid the crowded settings where they otherwise work and live. By contrast, India's lockdown caught most migrants in the cities, where many have no reason to be if they cannot work; as Harriss emphasizes, public relief efforts have been very limited, except in left-leaning Kerala (a long-standing exception to generalizations about Indian governments' indifference to the poor). Moreover, India's internal migrants are, on average, considerably poorer than China's, making them more vulnerable to start with. ${ }^{19}$ The World Bank's recent projections suggest that South Asia will account for about 40 percent of the additional people who will have 2021 incomes under $\$ 1.90$ per day because of COVID-19 and more than 60 percent of those pushed under $\$ 3.20$

\footnotetext{
${ }^{17}$ Scott Rozelle, Heather Rahimi, Huan Wang, and Eve Dill, "Lockdowns Are Protecting China's Rural Families from COVID-19, but the Economic Burden Is Heavy," IFPRI Blog, March 30, 2020, https://www.ifpri.org/blog/lockdowns-are-protecting-chinas-rural-families-covid-19-economicburden-heavy (accessed July 24, 2020).

${ }^{18}$ Katherine Mason, Infectious Change: Reinventing Chinese Public Health after an Epidemic (Stanford, Calif.: Stanford University Press, 2016), 3-4.

${ }^{19}$ Compare Harriss's observation that more than 60 percent of migrants earn less than 375 rupees (US\$5) per day, while Chinese migrant earnings probably average about US $\$ 600$ per month. See "Migrant Workers and Their Children," China Labour Bulletin, May 11, 2020, https://clb.org.hk/ content/migrant-workers-and-their-children (accessed July 24, 2020). (The $\$ 100$ billion loss cited earlier was, however, calculated with an estimate of $\$ 500$ per month.)
} 
per day; if the poverty cutoff is set at $\$ 5.50$, East Asia and the Pacific will also have very large numbers of additional poor, but still about half as many as South Asia. ${ }^{20}$

Border-crossing migrants generally have even less political leverage than domestic ones, and suffer accordingly. In June, dormitories for Singapore's migrant workers (about 25 percent of residents) accounted for 93 percent of its COVID infections; ${ }^{21}$ many more of these workers are facing dramatic income losses and social isolation. It is unclear how many of the more than eight million Philippine nationals working abroad are "stranded" by the coronavirus_one official has given a figure of 85,000, while other estimates are much, much, larger-but they are apparently receiving very little assistance, and government funds allocated for repatriating some of them will probably run out in August. ${ }^{22}$ The frequently used language of viral "hot spots" expresses entirely justifiable fears that devastation will eventually radiate outward from places and groups where it is currently concentrated, but it also reminds us that at any given moment, people's fortunes depend heavily on what sort of "spot" they happen to be in.

Stereotypes and blame games, however, generally aim at broad targets. "Indians," "Chinese," and/or "Asians" were labeled as hygienically deficient in earlier pandemics, not people from the specific origin points of outbreaks (especially if those origin points were actually Western). Thus this fourth, more discursive, topic orients us back to very large spatial scales.

Some Westerners, clearly, are racializing this pandemic, but their efforts are both different and less effective than the ones of which Arnold and (more briefly) Brazelton remind us. In part, this likely reflects changes in objective reality. The differences in life expectancy between even Asia's poorest nations and those of the West are narrower than they were fifty or a hundred years ago, and people in the richest Asian countries live as long as people anywhere. The familiar props of biomedicine are visible throughout Asia, at least in cities, and the faces behind many doctor's, nurse's, and other health care workers' masks in Europe and North America reflect Asian ancestry and/or birth. Meanwhile, many of the most visibly inept responses and highest death rates during the current crisis have been in wealthy Western countries - the United States, the United Kingdom, and Sweden-making old tropes of Asian deficiency more obviously false than they may once have seemed. Still, racial imaginings are rarely much constrained by reality, and some powerful people and institutions have sought to focus attention on the Chinese origins of the virus and the damage done by the Chinese government's initial response. However, poll results from the end of May suggested that only 34 percent of US voters thought the Chinese government bore the most

${ }^{20}$ Daniel Gerzhon Mahler, Christoph Lakner, R. Andres Castaneda, and Haoyu Wu, "Updated Estimates of the Impact of COVID-19 on Global Poverty," Data Blog, June 8, 2020, https:// blogs.worldbank.org/opendata/updated-estimates-impact-covid-19-global-poverty (accessed July 24, 2020).

${ }^{21}$ Kentaro Iwamoto, "Singapore Coronavirus Clusters Awaken Asia to Migrants' plight," Nikkei Asian Review, June 9, 2020, https://asia.nikkei.com/Spotlight/Asia-Insight/Singapore-coronavirusclusters-awaken-Asia-to-migrants-plight (accessed July 24, 2020).

${ }^{22}$ Raissa Robles, "Philippines' OFW Crisis: More than 700,000 Could Lose Their Jobs to Coronavirus by Year End," South China Morning Post, July 5, 2020, https://www.scmp.com/week-asia/ politics/article/3091797/philippines-ofw-crisis-more-700000-could-lose-their-jobs-due (accessed July 24, 2020). 
responsibility for COVID's spread (within the margin of error from those naming Trump as the chief culprit), while German polls suggested attitudes toward China actually becoming more positive recently (and those toward the United States more negative). Such results probably indicate some reduction in racism-at least anti-Chinese racism-over the long haul. ${ }^{23}$

To be sure, the image of "techno-Orientalism" that Kang highlights resonates with older tropes of obedient, easily controlled, Asians — and some reflections of that image can be found in serious journals as well as popular culture. But even this is a long way from once-common tropes of Asian helplessness and ignorance, or even indifference to human life-and from the relative silence of metropolitan media when, as in 1919, it was a Western plague that killed millions of Indians. (Indeed, just a few years later, the notorious Mother India found huge audiences in the United States and United Kingdom; imagining disease vectors opposite those of 1919, it predicted that unsanitary Indians would devastate the West if not properly controlled. ${ }^{24}$ ) Respectable sources still point to China, in particular, as a likely origin point for future pandemics. But that is because it is, for reasons-people pressing hard on certain animal habitats, raising hogs and fowl in close quarters, and an often lax regulatory state-that can hardly be labeled essentially "Oriental." (Eating animals that many Westerners consider exotic is another matter and has figured in some especially strident attempts to make this a "Chinese virus," but the same US poll cited earlier suggests strong opposition to blaming Chinese individuals, even as many respondents criticized the Chinese government.) When serious writers today invoke East Asian authoritarianism as a possible advantage amidst ecological disaster, this is less likely to be a critique of Asian societiesmuch less a claim that Asians are particularly prone to autocracy-than a critique of the current corruption of Western democracies. (Naomi Oreskes and Erik Conway's The Collapse of Western Civilization, with its all-too-plausible story of Western societies unable to override the influence of climate deniers, is a case in point.)

This brings us, then, to the virus's possible implications for geopolitics and the global economy. Here, too, I am struck less by what the pandemic might change than by what it reveals about how the world was already changing. Shortages of personal protective equipment (PPE) in the United States have been greatly exacerbated by the callousness and incompetence of its current administration; but one part of that incompetence was a government failure to adjust to outsourcing that began decades ago, which is unlikely to reverse. (Another is that, for all its intermittent China bashing, the Trump administration initially confirmed Beijing's misleading reassurances about the virus, probably because the president desperately needed a US-China trade deal.) Arnold's observation that a

\footnotetext{
23“"Voter Sentiment on Trump Pandemic Response Hits New Low," Morning Consult, June 1, 2020, https://morningconsult.com/2020/06/01/trump-pandemic-response-polling-low/ (accessed July 24, 2020); "Coronavirus Turns Germans More Critical of U.S.: Survey," Deutsche Welle, May 18, 2020, https://www.dw.com/en/coronavirus-turns-germans-more-critical-of-us-survey/a-53490316 (accessed July 24, 2020).

${ }^{24}$ Katherine Mayo, Mother India (New York: Blue Ribbon Books, 1927), especially chapter 27, "The World Menace, " 366-78; Mrinalini Sinha, Specters of Mother India: The Global Restructuring of an Empire (Durham, N.C.: Duke University Press, 2006).
} 
vaccine, wherever it might be discovered, is likely to be mass-produced in India is, likewise, reflective of what are now long-established facts of the worldwide division of labor.

Those developments have changed both the global economy and global politics. Whether Beijing's "mask diplomacy" is working is open to question, but its capacity and willingness to deploy substantial aid for political purposes is not. Nor does aid, or performance in the current crisis, seem capable of altering more fundamental political facts: Taiwan's own mask diplomacy (it is now the world's second-largest producer and exporter of PPE) has won it various thank yous, ${ }^{25}$ but not readmission to the World Health Organization or inclusion in the European Union's initial "safe list" for open travel (despite its remarkable success in crushing the virus at home). The current US government's responses - such as withdrawing from the World Health Organization-can only further the decline of its global influence. Whether they will also make people (both within and outside of China) forget the widely expressed anger about China's early handling of the pandemic is another question, but probably one with few immediate political consequences.

It is easy, then, to imagine a future in which COVID-19, for all the damage and chaos it has caused, largely winds up reinforcing preexisting trends on various levels. At the level of high politics, this is a picture in which failures to deal with COVID-19 accelerate social and political decay in much of the West, speeding an eastward shift in the world's political and economic center of gravity. In this story, the People's Republic of China would be the big winner politically. Economically, much of Asia might be relative winners, if judged as national units; however, no country would gain in absolute terms, and millions of individuals, especially in South Asia, would undergo terrible hardship. It is a scenario involving enormous pain, but not inconsistent with certain visions of a coming "Asian century." 26 At the very least, this would suggest that people elsewhere have much to learn by studying the relative resilience in this disaster of several East and Southeast Asian societies.

There is, however, at least one other, even gloomier way to look at this pandemic: not as a once-in-a-century event like the 1918-19 flu but as a harbinger of a succession of looming environmental disasters, including more pandemics. Several dynamics conducive to pandemics seem unlikely to abate: human encroachment on animal habitats continues apace, as does antibiotic-intensive animal husbandry; accelerating climate shifts will likely force and/or allow some disease-bearing creatures to occupy new habitats while extending the portion of the year in which they can survive. (Mosquitos surviving year-round farther from the equator than they do today is just one such possibility.) Meanwhile, we will have more directly weather-related disasters: stronger storms and heat waves, more coastal flooding, mega-droughts, and uncontrolled fires. Despite my earlier comments about humans' increased capacity to cope with a pandemic compared to our forebears, I see little in the last few months to suggest that any part of our world is

\footnotetext{
${ }^{25}$ Najee Woods, "Taiwan's Mask Diplomacy and the International Responses," Taiwan Insight, June 25, 2020, https:/taiwaninsight.org/2020/06/25/taiwans-mask-diplomacy-and-the-internationalresponses/ (accessed July 24, 2020).

${ }^{26}$ Amitav Ghosh cites examples of politicians who seem to believe that the costs of such catastrophes could be worth the power shift in The Great Derangement: Climate Change and the Unthinkable (Chicago: University of Chicago Press, 2016), 147-48.
} 
well positioned to handle repeated blows of that sort. Moreover, given how much loosely regulated economic growth has contributed to these looming threats, and how strongly numerous Asian governments have relied on growth to ameliorate numerous social ills during the last several decades, some of what now look like successes might be very vulnerable. If that turns out to be what COVID-19 portends, truly safe harbors might be very scarce, indeed.

\section{Acknowledgments}

My thanks to Nicole Barnes, Vinayak Chaturvedi, Robert Moeller, and Kaoru Sugihara for swift, helpful comments on earlier drafts of this essay. I am solely responsible for any errors. 